\section{The Effects of Short-term Drying on Seed Germination in Rosa}

\author{
David C. Zlesak ${ }^{1}$ \\ Department of Horticultural Science, University of Minnesota, 1970 Folwell \\ Avenue, St. Paul, MN 55108
}

Additional index words. achene, recalcitrant, Rosa rubiginosa, Rosa rugosa, Rosa setigera, rose
Seed propagation of roses is used for breeding new cultivars, native plant restoration, selected rootstocks, and some roses used for hip production (Gill and Pogge, 1974; Krüssmann, 1981; Weremark et al., 1995). Rose achenes (seeds) are notorious for having low viability and erratic germination (Buckley, 1985). Factors such as genetics, temperature during both seed maturation and stratification, scarification, pericarp removal, and plant growth regulators can affect germination frequency and uniformity (Buckley, 1985; Gudin et al., 1990; VonAbrams and Hand, 1956). Satisfactory viability has been retained for multiple years using dry longterm seed storage of Rosa multiflora Thunb. and other Rosaceous species (Crocker, 1926; Crocker and Barton, 1931). Short-term drying ( $<1$ month) is practiced in some rose breeding programs as a means to store early ripening seed within a family until the whole family is harvested or until seed from all crosses are cleaned and can be prepared for stratification simultaneously (Kathy Zuzek, personal communication). In blackberry, a closely allied species, a significant loss of germination occurred after only $12 \mathrm{~h}$ of drying (Mian et al., 1995). The effect of short-term drying on rose seed germination, relative to seeds exposed to constant moisture when germination does not need to be delayed, is unclear and is the focus of this investigation.

Rosa hybrida 'Bucbi' (Carefree Beauty) and 'George Vancouver' were chosen for this study because these cultivars have relatively high and moderate germination rates, respectively (Zlesak, 2001), and represent adapted germplasm being used in the development of additional cultivars (Cairns, 2000). Three rose species were also selected for this study. Rosa rubiginosa $\mathrm{L}$. is a species rose commercially raised for hip production and as a rootstock (Hortico, 2005; Werlemark et al., 1995) and has a relatively low germination rate (unpublished data). Rosa rugosa Thunb. and $R$. setigera Mich. represent species primarily used for naturalizing and landscape purposes. In addition, $R$. rubiginosa, $R$. rugosa, and $R$. setigera represent different sections of the genus Rosa;

Received for publication 14 May 2005. Accepted for publication 22 June 2005. This manuscript is Scientific Journal series 041210133 of the Department of Horticultural Science, University of Minnesota and has been supported in part by the Minnesota Agricultural Experiment station. The author thanks Byron Twiss for his technical assistance.

${ }^{1}$ Graduateresearchassistant; e-mailzlesak@rocketmail. com.
Caninae, Cinnamomeae, and Synstylae, respectively. 'Bucbi' and $R$. rubiginosa were used for year one data (2003-04) and all five roses were used for year two data (2004-05).

Open-pollinated hips were harvested when the hypanthia was fully orange and still firm, the optimum stage of development to maximize germination reported for $R$. canina $\mathrm{L}$. (Rowley, 1956). Achenes were extracted from hypanthium tissue within $24 \mathrm{~h}$ after harvest and were placed directly in distilled water. Only sinking seeds of 'Bucbi', 'George Vancouver', $R$. rubiginosa, and $R$. setigera were retained since floating seeds often have a higher proportion of nonviable embryos (Buckley, 1985). Seeds of R. rugosa are buoyant (Svejda, 1972); therefore, the float test was not used on this species. Under ambient laboratory conditions $\left(25^{\circ} \mathrm{C}\right.$ and $30 \%$ relative humidity $)>500$ seeds of each cultivar or species were allowed to air dry for four days, and at the same time $>500$ seeds of each cultivar or species were kept continually moist wrapped in damp paper towels within sealed polyethylene bags. After treatment, all seeds were submerged in distilled water for $24 \mathrm{~h}$. Five replications of 100 seeds were counted for each moisture treatment per cultivar or species per year. Each replication of seeds was mixed with $80 \mathrm{~cm}^{3}$ of moistened Canadian sphagnum peatmoss (Hyponex Corporation, Marysville, Ohio) and sealed in a $16.8 \times 14.9$-cm polyethylene bag (Glad zipper bags, Oakland, Calif.).

Seeds were cold stratified for 12 weeks at $4{ }^{\circ} \mathrm{C}$ and then moved to $14{ }^{\circ} \mathrm{C}$ for the duration over which germination was observed (11 weeks in year $1 ; 16$ weeks in year 2). Bags were monitored once per week at which time germinating seeds (seeds with an emerged radicle) were removed and counted. The 2 weeks $\left(X\right.$ and $\left.X_{+1}\right)$ bracketing the $50 \%$ total germination value and their cumulative ger- mination values ( $\mathrm{C}_{1}$ and $\mathrm{C}_{2}$, respectively) were used to calculate $\mathrm{T}_{50}$ for each replication with the following formula. Student's $t$ tests were calculated using SPSS software (SPSS 11.0 for Windows, Chicago, Ill. $): \mathrm{T}_{50}=\mathrm{X}+[(50 \%$ total germination $\left.\left.-\mathrm{C}_{1}\right) /\left(\mathrm{C}_{2}-\mathrm{C}_{1}\right)\right]$.

Short-term drying reduced total percent germination and altered $\mathrm{T}_{50}$ for $R$. rubiginosa and $R$. rugosa, but did not significantly affect germination of the other cultivars or species relative to constant moisture (Table 1, Fig. 1). A significantly longer $\mathrm{T}_{50}$ in response to shortterm drying was found for $R$. rubiginosa and shorter $\mathrm{T}_{50}$ for $R$. rugosa relative to constant moisture (Table 1). Some may consider the year 1 reduction in total percent germination (6.2\% reduction) for 'Bucbi' due to short-term drying to be slightly significant $(P=0.10)$ depending on where one sets their significance threshold, however, in year 2 a trend towards divergence between moisture treatments for 'Bucbi' $(0.2 \%$ reduction; $P=0.96)$ was not observed (Table 1, Fig. 1). The total percent germination was greater in year 2 at week 11 for both 'Bucbi' moisture treatments and the continuous moisture treatment for $R$. rubiginosa (Fig. 1). Different degrees of physiological dormancy across seed lots collected from the same parents in different years is common for many plant species and can be due to differing environmental conditions (Baskin and Baskin, 1998).

Depending on cultivar or species, germination improved or stayed the same when rose seeds were kept moist from harvest through germination relative to short-term drying after harvest. Roses and other Rosaceous species are not generally thought of as having recalcitrant seeds, since viability is generally satisfactory after drying (Crocker and Barton, 1931). In breeding programs where there is a high investment in hand-pollinated seed, not allowing seeds to dry out before stratification treatments could maximize both rapid and a high final percent of germination. Since commercial rose breeding programs generally try to obtain rapid germination after achene harvest and then raise seedlings in greenhouses (Krüssmann, 1981), keeping seeds continually moist should not interfere with established protocols and could easily be adopted. On the other hand, if seed is abundant, limited resources may be best allocated using dry storage to delay stratification treatments and germination, a situation which may occur when raising open-pollinated
Table 1. Total percent germination and number of weeks to $50 \%$ germination $\left(\mathrm{T}_{50}\right)$ for open-pollinated rose seed exposed to short-term drying (STDG) and constant moisture (CMT).

\begin{tabular}{|c|c|c|c|c|c|c|c|}
\hline \multirow[b]{2}{*}{$\begin{array}{l}\text { Cultivar } \\
\text { or species }\end{array}$} & \multirow[b]{2}{*}{ Year } & \multicolumn{3}{|c|}{ Total germination $(\%)^{\mathrm{z}}$} & \multicolumn{3}{|c|}{$\mathrm{T}_{50}$} \\
\hline & & $\begin{array}{c}\text { CMT } \\
\operatorname{Mean}(\mathrm{SD})\end{array}$ & $\begin{array}{c}\text { STDG } \\
\text { Mean (SD) }\end{array}$ & $P^{\mathrm{y}}$ & $\begin{array}{c}\text { CMT } \\
\text { Mean (SD) }\end{array}$ & $\begin{array}{c}\text { STDG } \\
\text { Mean (SD) }\end{array}$ & $P$ \\
\hline \multirow[t]{2}{*}{ 'Bucbi' } & 1 & $38.6(4.3)$ & $32.2(6.4)$ & 0.10 & $3.7(0.6)$ & $3.6(0.6)$ & 0.63 \\
\hline & 2 & $64.4(5.1)$ & $64.2(5.8)$ & 0.96 & $6.0(1.5)$ & $5.2(1.0)$ & 0.36 \\
\hline 'George Vancouver' & 2 & $9.2(2.8)$ & $8.2(2.3)$ & 0.55 & $2.2(0.5)$ & $2.2(0.3)$ & 0.91 \\
\hline \multirow{2}{*}{ R. rubiginosa } & 1 & $22.8(7.0)$ & $14.0(4.0)$ & 0.04 & $7.6(0.3)$ & $8.9(0.7)$ & 0.01 \\
\hline & 2 & $40.6(5.4)$ & $18.2(3.6)$ & $<0.01$ & $7.5(0.5)$ & $9.2(0.7)$ & $<0.01$ \\
\hline R. rugosa & 2 & $61.8(4.9)$ & $48.6(4.3)$ & $<0.01$ & $7.4(1.0)$ & $5.9(0.4)$ & 0.01 \\
\hline$R$. setigera & 2 & $90.0(2.3)$ & $90.8(3.6)$ & 0.68 & $0.6(0.0)$ & $0.6(0.0)$ & 0.53 \\
\hline
\end{tabular}

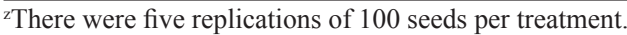

${ }^{y}$ An independent Student's $t$ test was calculated within cultivar or species within year comparing STDG and CMT for each dependant variable. 


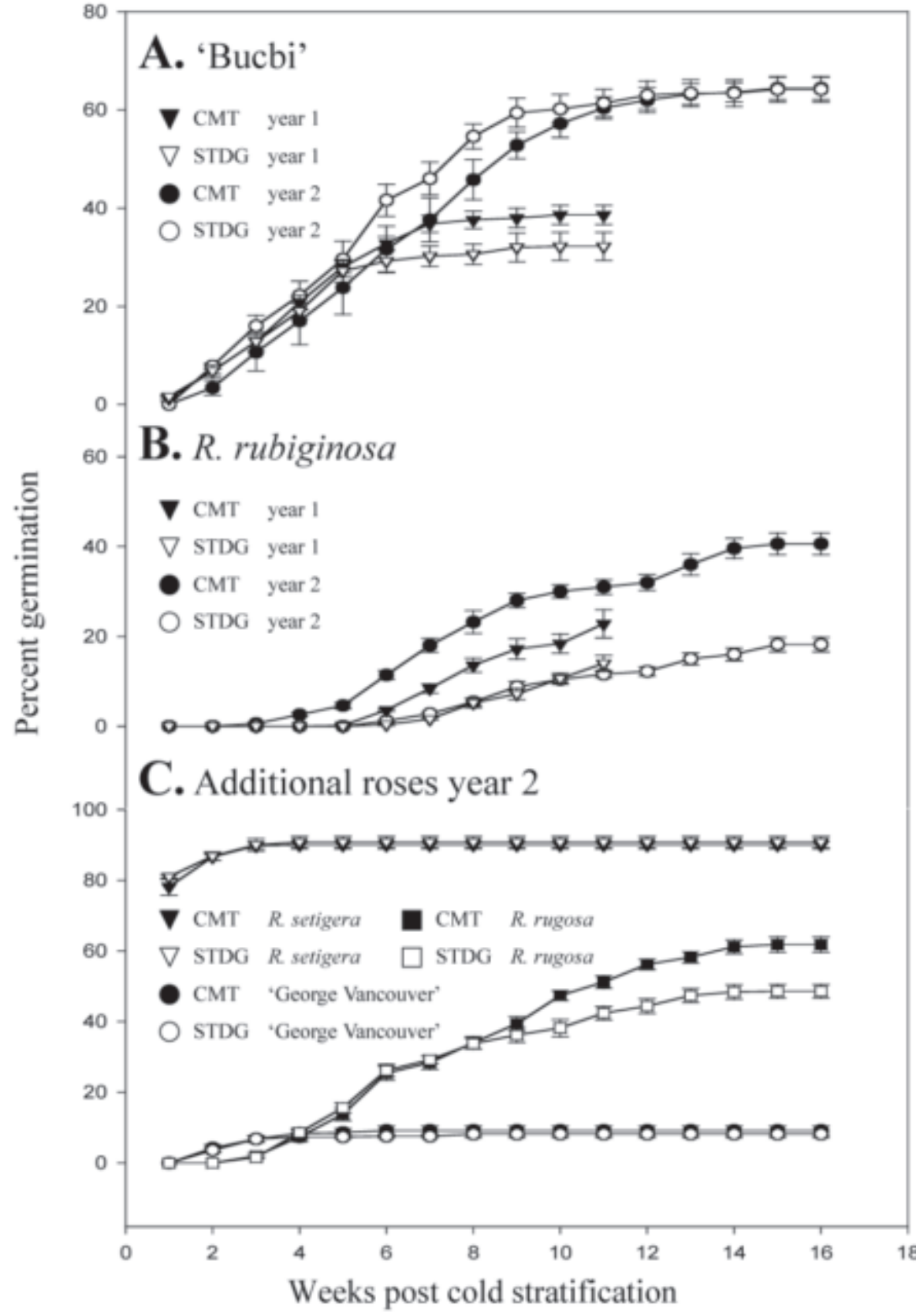

Fig. 1. Cumulative germination with standard errors from seed of (A) Rosa hybrida 'Bucbi', (B) R. rubiginosa, (C) R. hybrida 'George Vancouver', R. rugosa, and $R$. setigera exposed to short-term drying (STDG) and constant moisture (CMT).

seed of rose species with minimal dormancy like $R$. setigera and $R$. wichuraiana Crépin (Semeniuk and Stewart, 1962). Variablility for tolerance to $4 \mathrm{~d}$ of drying under ambient laboratory conditions was found among the tolerance relative to constant moisture using a grower's typical dry storage duration and conditions is warranted. Growers can determine how amenable their rose germplasm is to seed drying and then decide if viability loss, if experienced, is tolerable. If viability loss due to drying is not tolerable, exploring different germplasm sources, optimizing storage conditions, or changing production schedules may be justified.

\section{Literature Cited}

Baskin, C.C. and J.M. Baskin. 1998. Seeds, ecology, biogeography, and evolution of dormancy and germination. Academic Press. San Diego, Calif.

Buckley, F.C. 1985. Germination of rose achenes: A review and analysis of practices and some suggestions for future investigations. 1sted. The Amateur Rose Breeders Assn., England.

Cairns, T. (ed.). 2000. Modern roses XI, The world encyclopedia of roses. Academic Press, San Diego, Calif.

Crocker, W. 1926. After-ripening and germination of rose seeds. Amer. Rose Ann. 11:34-37.

Crocker, W. and L.V. Barton. 1931. After-ripening, germination, and storage of certain Rosaceous seeds. Boyce Thomp. Inst. Plant Res. 3:385-404.

Gill, J.D. and F.L. Pogge. 1974. Rosa L., rose, p. 732-737. In: C.S. Schopmeyer (ed.). Seeds of woody plants in the United States. USDA Agr. Hndbk. 450

Gudin, S., L. Aréne, A. Chavagnat, and C. Bulard. 1990. Influence of endocarp thickness on rose achene germination: Genetic and environmental factors. HortScience 25:786-788.

Hortico Nurseries Inc. 2005. Rose catalogue 2005. Hortico Nurseries, Watertown, Ontario.

Krüssmann, G. 1981. The complete book of roses. Timber Press, Portland, Ore.

Mian, M.A.R., R.M. Skirvin, M.A. Norton, and A.G. Otterbacher. 1995. Drying interferes with germination of blackberry (Rubus sp.) seeds in vitro. HortScience 30(1):124-126.

Rowley, G.D. 1956. Germination in R. canina.Amer Rose Ann. 41:70-73.

Semeniuk, P. and R.N. Stewart. 1962. Temperature reversal of after-ripening of rose seeds. J. Amer. Soc. Hort. Sci. 80:615-621.

Svejda, F. 1972. Water uptake of rose achenes. Can. J. Plant. Sci. 52:1043-1047.

VonAbrams, G.J. and M.E. Hand, 1956. Seed dormancy in Rosa as a function of climate. Amer. J. Bot. 43:7-12.

Werlemark, G.,U.Carlson-Nilsson, M. Uggla, and H. Nybom. 1995. Effects of temperature treatments on seedling emergence in dogroses, Rosa Sect. Caninae (L). Acta Agr. Scand. 45:278-282.

germplasm evaluated in this study (Table 1, Fig 1), offering limited information in predicting how other rose germplasm may respond. For rose germplasm where dry seed storage may be desirable, characterization of seed drying
Zlesak, D.C. 2001. Determining the value of parents based on seedling performance. Rose Hybridizers Assn. Nwsltt. 32(4)16-19. 